九州大学学術情報リポジトリ

Kyushu University Institutional Repository

\title{
Industrial Structure in Myanmar using a new Estimated Input-0utput Table (2000-2001)
}

\section{Thwin, Nana Khine Su}

Laboratory of Food Industrial Economics, Department of Agricultural and Resource Economics, Graduate School of Bioresource and Bioenvironmental Sciences, Kyushu University

Yoshida, Taiji

Laboratory of Food Industrial Economics, Department of Agricultural and Resource Economics, Graduate School of Bioresource and Bioenvironmental Sciences, Kyushu University

Maeda, Koshi

Laboratory of Food Industrial Economics, Department of Agricultural and Resource Economics, Graduate School of Bioresource and Bioenvironmental Sciences, Kyushu University

https://doi.org/10.5109/18856

出版情報：九州大学大学院農学研究院紀要. 55 (2)，pp. 387-396，2010-10-29. Faculty of Agriculture, Kyushu University

バージョン :

権利関係 : 


\title{
Industrial Structure in Myanmar using a new Estimated Input-Output Table (2000-2001)
}

\author{
Nan Khine Su THWIN ${ }^{1 *}$, Taiji YOSHIDA \\ and Koshi MAEDA \\ Laboratory of Food Industrial Economics, Department of Agricultural and \\ Resource Economics, Faculty of Agriculture Kyushu University, \\ Fukuoka 812-8581, Japan \\ (Received June 30, 2010 and accepted July 9, 2010)
}

\begin{abstract}
In most Asian countries, input-output tables have successfully complied for every five years. In Myanmar, the last input-output table was constructed in (1994-95). The investigation of industrial structure of Myanmar economy by using input-output analysis is not fully documented yet. This study illustrates the full current picture of sectoral development of Myanmar economy by using input-output model with the help of newly estimated input-output table of Myanmar. The results of this study have revealed that agricultural sector and processing \& manufacturing sector are the two most important sectors for the extension of primary inputs market and enhancing GDP and export of Myanmar.
\end{abstract}

Keywords: Input-output model, newly estimated input-output table, industrial structure, important sectors, Myanmar economy

\section{INTRODUCTION}

It is very important for national planning of policy maker to understand the situation of the sectoral development and the flow of goods and services within the national economy. The input-output analysis was pioneered by professor Wassily. W. Leontief in the early 1930 and it is the popular means of analyzing regional economic structure and assisting local economic development decision making. Input-output analysis describes and explains the level of output of a given national economy in terms of its relationships to the corresponding level of activities in all the other sectors. In input-output analysis, the economy is classified into sectors (or industries) and the flow of goods and services among sectors or industries is registered to indicate systematically the relations among them. These relations are called input-output relations because they tell us what inputs a sector needs to produce its output.

The application of input-output analysis required the preparation of input-output table of the economy. An input-output table permits us to analyze the interrelationship and to determine the effects on all industries of a change in the demand for any one of them. Input-output table provide the varieties of useful information [Deller 1990]: It is descriptive tool showing the existing structure of regional economy: It provides information on individual economic sectors: the linkage between them and how they co-vary: It can show the relative important of individual sector to overall economy: It can predict local response to changing economic conditions.

In Myanmar, the first input-output table was con-

${ }^{1}$ Laboratory of Food Industrial Economics, Department of Agricultural and Resource Economics, Graduate School of Bioresource and Bioenvironmental Sciences, Kyushu University

* Corresponding Author ( E-mail: herostar@agr.kyushu-u.ac.jp) structed by Professor Tun Thin, Professor Sun drum and U Aye Hlaing in (1952-53). The second table was built by U Nyunt Maung, Ministry of National Planning, and U Than Nyunt, Institute of Economics in (1964-65). The third table was drawn by Daw Tin Tin Yu in (1969-70). The fourth table was constructed by Daw Cho Cho Myint in (1989-90). The last table was built by Daw Tin Tin Yu in (1994-95). Apart from (1989-90) and (1994-95) tables, the remaining tables were drawn base on the twelve sectors.

Now, in many developed countries as well as in developing countries, the construction and the use of inputoutput table in empirical analysis have become a common practice. In Asian region, most of the countries have successfully compiled the table for every five years. In Myanmar, the last input-output table was constructed in 1994-95. So we have no up-to date input-output table that was constructed after the last table. In the previous studies, the investigation of industrial structure of Myanmar economy by using input-output analysis is not fully documented yet. It is required to develop up-to-date and comprehensive input-output table for the recent year and to analyze this new table to understand the full current picture of sectoral development of Myanmar's economy.

The main objective of this study is to investigate the characteristics of industrial structure of Myanmar economy (2000-2001) by using input-output technique. It is essential to draw up a new input-output table for Myanmar in that period. So the specific objective of this study is to estimate new input-output table of Myanmar (20002001).

In this study, non surveys (secondary data) were used for updating, estimating and analyzing the table. Inputoutput table for Myanmar (2000-2001) was prepared with the help of (1985-86) input-output table as a base and the existing sources of information from SNA (System of National Account) of Myanmar. On the account of 
limitation in situation, (2000-2001) input-output table was constructed $(13 \times 13)$ matrix as same as (1985-86) base table.

This paper illustrates the characteristics of industrial structure of Myanmar economy with the help of new estimated input-output table (2000-2001). The present table was built five years after the last input-output table. This table has presented the situation of industrial structure of Myanmar economy base on thirteen economic sectors. Moreover, the comparison between input-output tables of Myanmar and Japan was made in every step for recognizing the differences in sectoral activities between developed and developing country.

\section{AN ESTIMATION Of NEW INPUT-OUTPUT TABLE}

\section{Method of estimation}

\section{Input-output model and basic table}

In this paper, Leontief's input-output model was used to estimate new input-output table of Myanmar (20002001). Our estimation was based on input-output table of Myanmar (1985-86) and the secondary data from SNA (System of National Account). Leontief's input-output model was briefly explained by the hypothetical inputoutput transaction table as shown in table (1).

Gross outputs $($ sale $)=$ Intermediate demand + final demand

$$
X_{i}=\sum_{j=1}^{n} x_{i j}+\left(C_{i}+I_{\mathrm{i}}+E_{i}\right)
$$

Gross inputs (purchase) $=$ Intermediate inputs + primary inputs

$$
X_{j}=\sum_{i=1}^{n} x_{i j}+\left(V_{j}+M_{j}\right)
$$

Where,

$\mathrm{x}_{\mathrm{ij}}=$ the amount of the product of industry (sector) $\mathrm{i}$ absorbed annually as an intermediate input by industry $\mathrm{j}$, $X_{i}=$ total output of $i^{\text {th }}$ sector, $E=$ export of $i^{\text {th }}$ sector, $C_{i}$
$=$ household's consumption of product of $\mathrm{i}^{\text {th }}$ sector, $\mathrm{I}_{\mathrm{i}}=\mathrm{i}^{\text {th }}$ sector investment, $\mathrm{V}_{\mathrm{j}}=$ value added in sector $\mathrm{j}, \mathrm{M}_{\mathrm{j}}=$ imports for $\mathrm{j}^{\text {th }}$ sector, For $\mathrm{i}, \mathrm{j}=1,2, \ldots, \mathrm{n}$ assuming that there are n sector.

In the above table, rows represent input and columns designate output. Therefore, each sector is both a user of inputs and the producer of outputs. The total outputs of each sector are divided into intermediate demand and final demand for its goods and services. Also, the total inputs of each sector are divided into intermediate supply and value added, which represent the supply of primary inputs or factors of production needed by sector. The necessary condition of input-output table is the total output must be equal to total inputs.

$$
\begin{aligned}
& X_{i}=X_{j} \\
& \text { Since, } \sum_{i=1}^{n} x_{i j}=\sum_{j=1}^{n} x_{i j} \\
& V+M=C+I+E \\
& V=C+I+(E-M)
\end{aligned}
$$

That is, the sum of the total income generated by the production system of economy is equal to the total value of finished goods and services purchased by the final sectors for consumption, investment and net exports.

\section{Updating and balancing new table}

The transaction method under input-output model was used for updating new input-output table of Myanmar. In this method, base period inter-industry transactions are made proportion to the base period value added. We can calculate input coefficient matrix of base year induced

\begin{tabular}{|c|c|c|c|c|c|}
\hline \multirow{3}{*}{$\begin{array}{l}\text { Producing } \\
\text { Sector } \\
\text { (Outputs) }\end{array}$} & \multirow{3}{*}{$\begin{array}{l}\text { Intermediate use columns } \\
1,2 \ldots \mathrm{j} \ldots \mathrm{n}\end{array}$} & \multicolumn{3}{|c|}{ Using sector (inputs) } & \multirow{3}{*}{ Total Output } \\
\hline & & & Final Use & & \\
\hline & & Consumption & Investment & Export & \\
\hline \multirow{5}{*}{$\begin{array}{r}\text { Rows } 1 \\
2 \\
. \\
.\end{array}$} & $\mathrm{x}_{11} \mathrm{x}_{12} \ldots \mathrm{x}_{1 \mathrm{j}} \ldots \mathrm{x}_{1 \mathrm{n}}$ & $\mathrm{C}_{1}$ & $\mathrm{I}_{1}$ & $\mathrm{E}_{1}$ & $\mathrm{X}_{1}$ \\
\hline & $x_{21} x_{22} \ldots x_{2 j} \ldots x_{2 n}$ & $\mathrm{C}_{2}$ & $\mathrm{I}_{2}$ & $\mathrm{E}_{2}$ & $\mathrm{X}_{2}$ \\
\hline & $\ldots \ldots \ldots \ldots \ldots$ & . & . & . & . \\
\hline & $\ldots \ldots \ldots \ldots \ldots$ & . & . & . & . \\
\hline & $\ldots \ldots \ldots \ldots$ & & . & & $\mathrm{N}$ \\
\hline $\mathrm{i}$ & $\mathrm{x}_{\mathrm{i} 1} \mathrm{x}_{\mathrm{i} 2} \ldots \mathrm{x}_{\mathrm{ij}} \ldots \mathrm{x}_{\mathrm{in}}$ & $\mathrm{C}_{\mathrm{i}}$ & $\mathrm{I}_{\mathrm{i}}$ & $\mathrm{E}_{\mathrm{i}}$ & $X_{i}$ \\
\hline . & $\ldots \ldots \ldots \ldots \ldots$ & 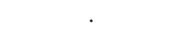 & . & $\cdot$ & $\cdot$ \\
\hline n & $x_{n 1} x_{n 2} \ldots x_{n j} \ldots x_{n n}$ & $\mathrm{C}_{\mathrm{n}}$ & $\mathrm{I}_{\mathrm{n}}$ & $\mathrm{E}_{\mathrm{n}}$ & $X_{n}$ \\
\hline Value Added & $V_{1} V_{2} \ldots V_{j} \ldots V_{n}$ & $\mathrm{~V}_{\mathrm{c}}$ & $\mathrm{V}_{\mathrm{I}}$ & $\mathrm{V}_{\mathrm{E}}$ & $\mathrm{V}$ \\
\hline Imports & $\mathrm{M}_{1} \mathrm{M}_{2} \ldots \mathrm{M}_{\mathrm{j}} \ldots \mathrm{M}_{\mathrm{n}}$ & $\mathrm{M}_{\mathrm{c}}$ & $\mathrm{M}_{\mathrm{I}}$ & $\mathrm{M}_{\mathrm{E}}$ & M \\
\hline Total Inputs & $X_{1} X_{2} \ldots X_{j} \ldots X_{n}$ & $\mathrm{C}$ & I & $\mathrm{X}_{\mathrm{E}}$ & $\mathrm{X}$ \\
\hline
\end{tabular}
by value added of this year by following:

$$
a_{i j}(1985-86)=x_{i j}(1985-86) / V_{j}(1985-86)
$$

Where, $\mathrm{a}_{\mathrm{ij}}$ is input coefficient matrix, $\mathrm{x}_{\mathrm{ij}}$ is the intermediate items and $V_{j}$ is the value added of (1985-86).

Table 1. Hypothetical input-output transaction table 
This matrix of proportions is multiplied by the diagonal matrix of the value added for the predicted year to form the transaction matrix of that year. It can be defined as

$$
x_{i j}(2000-01)=a_{i j}(1985-86) \times V_{j}(2000-01)
$$

Here, $\mathrm{x}_{\mathrm{ij}}$ is the new needed transaction matrix of (20002001).

In the case of the final demand items for the future table, the base year final demand items are divided by final demand total of base period. This proportion is multiplied by total final demand of target year is defined by

$$
F_{i l}{ }^{\prime}(1985-86)=F_{i l}(1985-86) / F_{i t}(1985-86)
$$

$$
F_{i l}(2000-01)=F_{i l}{ }^{\prime}(1985-86) \times F_{i t}(2000-01)
$$

Here $\mathrm{F}_{\mathrm{it}}$ is total final demand items and $\mathrm{F}_{\mathrm{il}}$ is the individual final demand of consumption, investment, government expenditure and export.

The estimated table obtained by using Leontief's input-output model was unbalanced where the row and column sum did not match. So RAS method proposed by Richard Stone in 1960 was used for balancing the new estimated table. The estimated new table was adjusted to sum to the given row and column totals for the updated year, by successive prorating of the rows and columns until consistency is achieved by the following;

\begin{tabular}{|c|c|c|c|c|c|c|c|c|c|c|c|c|c|c|c|}
\hline No & Sector & 1 & 2 & 3 & 4 & 5 & 6 & 7 & 8 & 9 & 10 & 11 & 12 & 13 & $\begin{array}{c}\text { Total } \\
\text { Intermediate } \\
\text { Use (14) }\end{array}$ \\
\hline 1 & Agricultural & 80,858 & 7,639 & 116 & 0 & 592,189 & 0 & 0 & 186 & 0 & 0 & 0 & 70 & 0 & 681,058 \\
\hline 2 & Livestock \& Fishery & 18,352 & 2,077 & 60 & 0 & 4,980 & 0 & 0 & 858 & 0 & 0 & 0 & 12 & 0 & 26,339 \\
\hline 3 & Forestry & 387 & 203 & 0 & 0 & 3,772 & 0 & 1,864 & & & & & 83 & 0 & 6,309 \\
\hline 4 & Mining & 0 & 0 & 0 & 26 & 1,909 & 1,086 & 1,854 & 0 & 0 & 0 & 0 & 0 & 0 & 4,875 \\
\hline 5 & Processing \& Manufacturing & 21,232 & 84,747 & 5,860 & 6,056 & 65,186 & 219 & 60,975 & 39,070 & 1,012 & 1,486 & 23,987 & 3,248 & 97,420 & 410,498 \\
\hline 6 & Power & 0 & 80 & 18 & 19 & 1,210 & 27 & 133 & 169 & 32 & 2 & 119 & 11 & 96 & 1,916 \\
\hline 7 & Construction & 6,357 & 275 & 73 & 76 & 3,393 & 1,811 & 0 & 47,543 & 44 & 6 & 6,611 & 222 & 25,675 & 92,086 \\
\hline 8 & Transportation & 10,149 & 14,207 & 677 & 714 & 120,628 & 296 & 16,376 & 4,151 & 175 & 22 & 1,785 & 472 & 81,251 & 250,903 \\
\hline 9 & Communication & 154 & 270 & 60 & 63 & 1,466 & 46 & 224 & 427 & 54 & 7 & 551 & 72 & 4,998 & 8,392 \\
\hline 10 & Financial Sector & 454 & 70 & 0 & 0 & 451 & 0 & 0 & 0 & 0 & 0 & 0 & 0 & 0 & 975 \\
\hline 11 & $\begin{array}{l}\text { Social \& Administrative } \\
\text { Services }\end{array}$ & 0 & 0 & 0 & 0 & 0 & 0 & 0 & 0 & 0 & 0 & 0 & 0 & 0 & 0 \\
\hline 12 & Rental \& Other Services & 0 & 0 & 0 & 0 & 0 & 0 & 0 & 0 & 0 & 0 & 110 & 43 & 1,990 & 2,143 \\
\hline 13 & Trade & 45,073 & 21,176 & 445 & 184 & 44,689 & 86 & 21,898 & 12,076 & 8 & 95 & 2,329 & 1,980 & 4,911 & 154,950 \\
\hline 14 & Total Purchase & 183,016 & 130,744 & 7,309 & 7,138 & 839,873 & 3,571 & 103,324 & 104,480 & 1,325 & 1,618 & 35,492 & 6,213 & 216,341 & $1,640,444$ \\
\hline 15 & Imports & 1,087 & 87 & 0 & 2 & 3,078 & 4 & 605 & 117 & 0 & 0 & 31 & 31 & 92 & 5,134 \\
\hline 16 & Labor Cost & 593,239 & 22,454 & 11,247 & 4,143 & 70,054 & 1,460 & 44,728 & 88,802 & 5,808 & 172 & 39,247 & 4,635 & 96,345 & 982,334 \\
\hline 17 & Depreciation & 159,186 & 3,793 & 133 & 3,799 & 16,839 & 2,652 & 974 & 36,321 & 611 & 10 & 31 & 11,909 & 4,308 & 240,567 \\
\hline 18 & Taxes (indirect) & 21,389 & 2,326 & 2,556 & 745 & 18,648 & 447 & 292 & 10,409 & 34 & 8 & 77 & 1,899 & 149,147 & 207,977 \\
\hline 19 & Surplus (profit or Losses) & 471,624 & 172,806 & 398 & 1,508 & 77,355 & 3,724 & 49 & 10,773 & 611 & 2,451 & 0 & 16,672 & 363,885 & $1,121,855$ \\
\hline 20 & Value added & $1,245,438$ & 201,379 & 14,333 & 10,194 & 182,897 & 8,283 & 46,044 & 146,305 & 7,065 & 2,641 & 39,354 & 35,114 & 613,686 & $2,552,733$ \\
\hline 21 & Total inputs & $1,429,541$ & 332,210 & 21,642 & 17,334 & $1,025,848$ & 11,858 & 149,972 & 250,902 & 8,390 & 4,259 & 74,877 & 41,358 & 830,119 & $4,198,309$ \\
\hline
\end{tabular}

$$
r_{i}^{(1) d e f}=y_{i} / \sum_{j} x_{i j}
$$

\begin{tabular}{|c|c|c|c|c|c|c|}
\hline \multirow{2}{*}{ No } & \multirow{2}{*}{ Sector } & \multicolumn{4}{|c|}{ Final Use (Demand) } & \multirow{2}{*}{ Total Output } \\
\hline & & Consumption & Investment & Export & Total Final Demand & \\
\hline 1 & Agricultural & 666,319 & 74,837 & 7,327 & 748,483 & $1,429,541$ \\
\hline 2 & Livestock \&Fishery & 293,252 & 12,213 & 407 & 305,872 & 332,210 \\
\hline 3 & Forestry & 5,624 & 7,282 & 2,426 & 15,332 & 21,642 \\
\hline 4 & Mining & 5,357 & 6,762 & 341 & 12,460 & 17,334 \\
\hline 5 & $\begin{array}{l}\text { Processing \& } \\
\text { Manufacturing }\end{array}$ & 539,239 & 74,771 & 1,339 & 615,349 & $1,025,848$ \\
\hline 6 & Power & 2,187 & 7,755 & 0 & 9,942 & 11,858 \\
\hline 7 & Construction & 3,273 & 54,614 & 0 & 57,887 & 149,972 \\
\hline 8 & Transportation & 0 & 0 & 0 & 0 & 250,902 \\
\hline 9 & Communication & 0 & 0 & 0 & 0 & 8,390 \\
\hline 10 & Financial & 3,246 & 38 & 0 & 3,284 & 4,259 \\
\hline \multirow[t]{2}{*}{11} & Social \& & & & & & \\
\hline & $\begin{array}{l}\text { Administrative } \\
\text { Services }\end{array}$ & 63,835 & 11,042 & 0 & 74,877 & 74,877 \\
\hline \multirow[t]{2}{*}{12} & Rental \& Other & & & & & \\
\hline & Services & 39,214 & 0 & 0 & 39,214 & 41,358 \\
\hline 13 & Trade & 608,415 & 65,954 & 799 & 675,168 & 830,119 \\
\hline 14 & Total Purchase & $2,229,961$ & 315,268 & 12,639 & $2,557,868$ & $4,198,310$ \\
\hline 15 & Imports & 7,517 & 2,422 & 0 & 9,939 & 15,073 \\
\hline
\end{tabular}

Table 2. New estimated input-output table of Myanmar for the year (2000-2001) (million kyat)

(*kyat represents Myanmar currency) 


$$
\begin{aligned}
& S^{(1) d e f}=z_{j} / \sum_{i} x_{i j} \\
& R^{(1)}=\max _{i}\left\{\left|r_{i}^{(1)}-1\right|\right\} \\
& S^{(1)}=\max _{j}\left\{\left|s_{j}^{(1)}-1\right|\right\} \\
& x_{i j}^{(2)}=r_{i}^{(1)} x_{i j} s_{j}^{(1)}
\end{aligned}
$$

The above notation show the first step of adjusting where $r$ is the ratio of given total outputs and computed total outputs and $\mathrm{s}$ is the ratio of a given total inputs and computed total inputs. And also $\mathrm{R}$ is the maximum absolute value of vector $\mathrm{r}^{\mathrm{i}}$ and unit vector and $\mathrm{S}$ is the maximum absolute value of vector $\mathrm{s}^{\mathrm{i}}$ and unit vector. To reach the necessary condition of input-output table that total inputs must be equal total output, we need to calculate until $\mathrm{k}^{\text {th }}$ step where $\mathrm{R}^{(\mathrm{k})}$ and $\mathrm{S}^{(\mathrm{k})}$ less than zero tolerance.

\section{Results of estimation}

New Input-output table of Myanmar (2000-2001)

According to the specific objective, the new and balance input-output table of Myanmar (2000-2001) can be successfully estimated with the help of secondary data by using Leontief's input-output model and RAS method. It was shown in table (2)

\section{Technical coefficient}

From the new input-output table of Myanmar (20002001), we can estimate technical coefficient also called input coefficient of that year. That can be expressed by the following equation.

$$
a_{i j}=\frac{x_{i j}}{X_{j}} i=1,2,3 \ldots 13, j=1,2,3 \ldots 13
$$

Where $\mathrm{a}_{\mathrm{ij}}$ is the technical coefficient of the production of each sector which indicates how many unit of output of $i^{\text {th }}$ sector needed to produce one unit of the output of $j^{\text {th }}$ sector. The input coefficient shown under any endogenous sector column represents the relative importance of the output of the sector indicated by each sector row.
This amount of output is the amount of the input absorbed by each sector. We will now examine the magnitudes of the input coefficient for each sector in table (3).

Most economic sectors use inputs from at least six economic sectors whereas processing \& manufacturing sector applies inputs from eleven economic sectors. It can be interpreted that processing \& manufacturing sector is an essential sector for the input market of our country. The input coefficient of agricultural sector row under the column of processing and manufacturing sector (0.5772) and it is the largest of the entire input coefficient. This coefficient shows that the processing and manufacturing sector uses the largest inputs from agricultural sector. This is because of processing and manufacturing sector includes a large number of the small scale agriculture based industries.

The second, the third and the fourth largest technical coefficient are (0.4065), (0.3493) and (0.3489) respectively. These are the technical coefficient of the row of processing \& manufacturing sector under the column of construction sector, mining sector and financial sector respectively. It shows that processing \& manufacturing sector produce the largest input requirements of our economy.

\section{ANALYSIS AND RESULTS USING ESTIMATED TABLE}

The second step of this paper is to analyze the industrial sector of Myanmar economy by using the new estimated input-output table that is the result of the first section. In the method of analysis, induced domestic product, one sector exogenous model, power and sensitivity of dispersion of sectors were applied for fulfilling the main objective of the study. In addition to this, the comparison between input-output table of Myanmar and Japan were also made in this section.

\section{Comparative analysis of induced domestic product between Myanmar and Japan}

Induced domestic product mean the domestic pro-

Table 3. Input coefficient matrix of Myanmar (2000-2001)

\begin{tabular}{rrrrrrrrrrrrrrr}
\hline No. & 1 & 2 & 3 & 4 & 5 & 6 & 7 & 8 & 9 & 10 & 11 \\
\hline 1 & 0.0565 & 0.0229 & 0.0053 & 0 & 0.5772 & 0 & 0 & 0.0007 & 0 & 0 & 0 & 0.0016 & 0 \\
2 & 0.0128 & 0.0062 & 0.0027 & 0 & 0.0048 & 0 & 0 & 0.0034 & 0 & 0 & 0 & 0.0002 & 0 \\
3 & 0.0002 & 0.0006 & 0 & 0 & 0.0036 & 0 & 0.0124 & 0 & 0 & 0 & 0 & 0.0020 & 0 \\
4 & 0 & 0 & 0 & 0.0015 & 0.0018 & 0.0915 & 0.0123 & 0 & 0 & 0 & 0 & 0 & 0 \\
5 & 0.0148 & 0.2551 & 0.2707 & 0.3493 & 0.0635 & 0.0184 & 0.4065 & 0.1557 & 0.1206 & 0.3489 & 0.3203 & 0.0785 & 0.1173 \\
6 & 0 & 0.0002 & 0.0008 & 0.0010 & 0.00118 & 0.0022 & 0.0008 & 0.0006 & 0.0038 & 0.0004 & 0.0015 & 0.0002 & 0.0001 \\
7 & 0.0044 & 0.0008 & 0.0033 & 0.0043 & 0.0033 & 0.1527 & 0 & 0.1894 & 0.0052 & 0.0014 & 0.0882 & 0.0053 & 0.0309 \\
8 & 0.0070 & 0.0427 & 0.0312 & 0.0411 & 0.1175 & 0.0249 & 0.1091 & 0.0165 & 0.02085 & 0.0051 & 0.0238 & 0.0114 & 0.0978 \\
9 & 0.0001 & 0.0008 & 0.0027 & 0.0036 & 0.0014 & 0.0038 & 0.0014 & 0.0017 & 0.0064 & 0.0010 & 0.0073 & 0.0017 & 0.0060 \\
10 & 0.0003 & 0.0002 & 0 & 0 & 0.0004 & 0 & 0 & 0 & 0 & 0 & 0 \\
11 & 0 & 0 & 0 & 0 & 0 & 0 & 0 & 0 & 0 & 0 & 0 \\
12 & 0 & 0 & 0 & 0 & 0 & 0 & 0 & 0 & 0 & 0 & 0.0014 & 0.0010 & 0.0023 \\
13 & 0.0315 & 0.0637 & 0.0205 & 0.0106 & 0.0435 & 0.00725 & 0.1460 & 0.0481 & 0.0009 & 0.0223 & 0.0311 & 0.0478 & 0.0059 \\
\hline
\end{tabular}


duction of every industry induced by individual final demand items which are consumption expenditures outside of household, consumption expenditures of households, consumption expenditures of government, gross domestic fixed capital formation, increases in stocks and exports. In this study, only two items of final demand (total final demand and export) were used to analyze the situation of Myanmar's industrial structure in 2000-2001. That can be expressed as $X=[I-A]^{-1} F$ (where $\mathrm{X}=$ induced domestic product, $[\mathrm{I}-\mathrm{A}]^{-1}=$ inverse matrix and $\mathrm{F}=$ final demand) and $X_{E}=[I-A]^{-1} E$ (where $\mathrm{X}_{\mathrm{E}}=$ induced domestic product by export and $\mathrm{E}=$ export)

Figure (1) and (2) indicate the comparison of induced domestic product by total final demand item and export item of Myanmar and Japan. The index of the domestic product induced by total final demand items of construction sector is the highest among thirteen economic sectors in Myanmar economy in 2000-2001. Although Myanmar is an agricultural country, the index of induced domestic
Table 4. Comparative induced domestic product coefficient by final demand item between Myanmar (2000-2001) and Japan (2000)

\begin{tabular}{clcc}
\hline No & \multicolumn{1}{c}{ Sector } & Myanmar & Japan \\
\hline 1 & Agriculture & 1.20 & 1.62 \\
2 & Livestock \& fishery & 1.77 & 2.09 \\
3 & Forestry & 1.70 & 1.51 \\
4 & Mining & 1.86 & 2.92 \\
5 & Processing \& manufacturing & 2.15 & 2.11 \\
6 & Power & 1.64 & 1.61 \\
7 & Construction & 2.35 & 1.95 \\
8 & Transportation & 1.90 & 1.83 \\
9 & Communication & 1.33 & 1.63 \\
10 & Financial & 1.80 & 1.50 \\
11 & Social \& administrative & 2.00 & 1.52 \\
12 & Rental \& other services & 1.29 & 1.55 \\
13 & Trade & 1.53 & 1.47 \\
\hline
\end{tabular}

Source : Model output

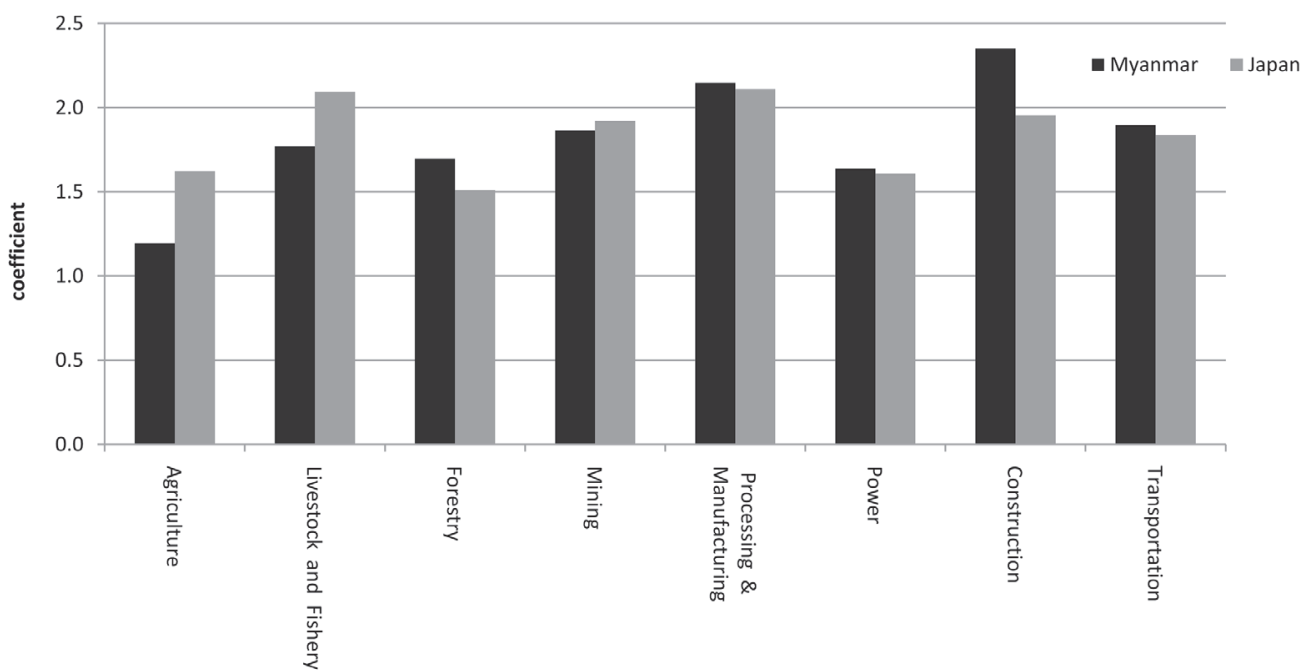

Source : Model output

Figure 1. Comparative induced domestic product by final demand item between Myanmar (2000-2001) and Japan (2000).

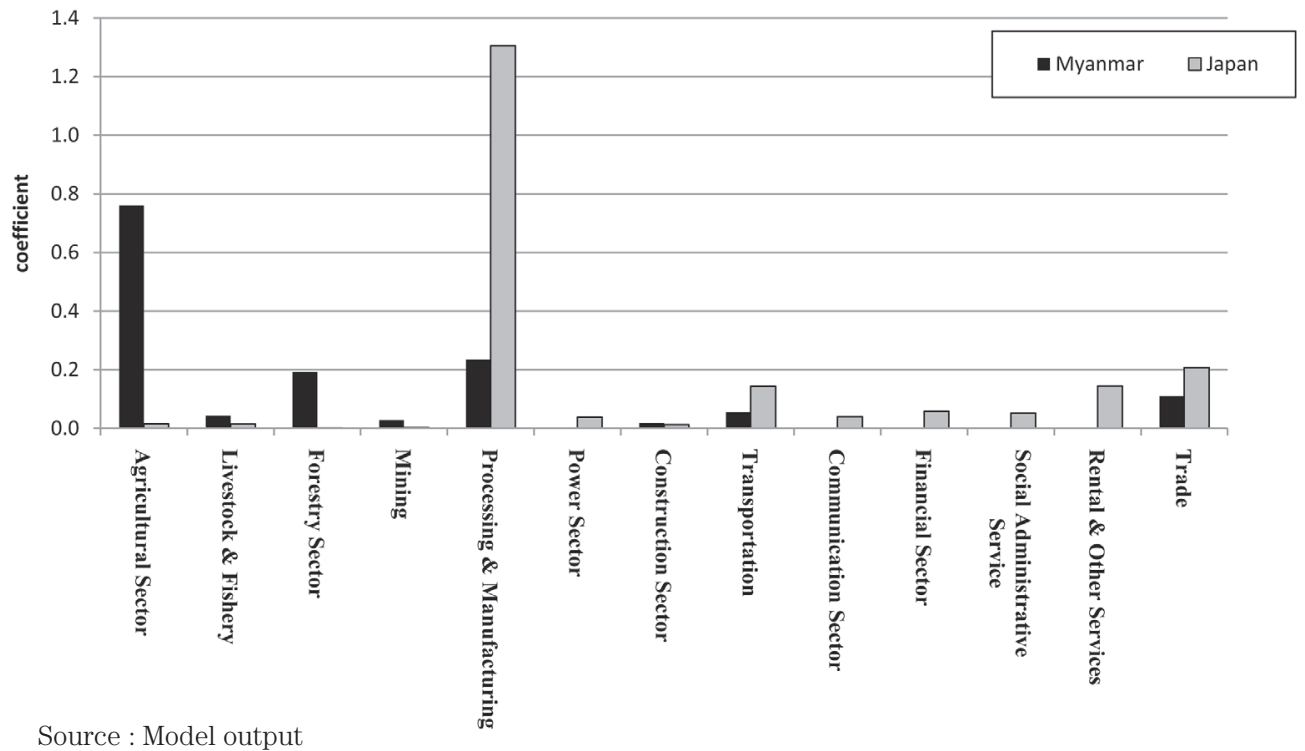

Figure 2. Comparative induced domestic product by export of Myanmar (2000-2001) and Japan (2000). 
product by total final demand of agricultural sector is the lowest among thirteen economic sectors and it is lowers than non agricultural country, Japan in the same period. In that case, the index of that of other sectors are negligible amount. So the expression of those sectors were omitted in this paper. But when we see the domestic product induced by export point of view, the index of agricultural sector is the highest of all industrial sectors in Myanmar's economy in (2000-2001). It can be interpreted that agricultural sector play the most important role for increasing export of our economy.

\section{Analysis of multiplicative effect of sectors: Power of dispersion and Sensitivity of dispersion}

Analysis of multiplicative effect of sector consists of the investigation of power of dispersion and sensitivity of dispersion of individual sector of the economy. It can also display the relative important of each sector of the economy. In this paper, we compare the characteristics of each sector of Myanmar's economy and Japan's economy in 2000-2001.

Power of dispersion of sector can be calculated by dividing the vertical sum of every column sector of inverse matrix coefficient matrix and the mean value of vertical sum. It gives the multiplicative effect of unit final demand of every column sector on all industries. It can be shown as, $\alpha_{j} / \bar{\alpha}$.

Where $\alpha_{j}=\sum_{i=1}^{n} b_{i j}$ and it is the vertical sum of inverse matrix, $\bar{\alpha}=\frac{\sum_{j} \alpha_{j}}{n}, \mathrm{n}$ is the number of sectors in the economy.

The horizontal sum of every row sector of the inverse matrix coefficient divided by the mean value of horizontal sum is called "sensitivity of dispersion by sector". It gives the multiplicative effect of unit demand about all column sector on every row sector and express as, $\beta_{i} / \bar{\beta}$.
Table 5. Comparative induced domestic product coefficient by export item of Myanmar (2000-2001) and Japan (2000)

\begin{tabular}{rlcc}
\hline No & \multicolumn{1}{c}{ Sector } & Myanmar & Japan \\
\hline 1 & Agriculture & 0.7607 & 0.0180 \\
2 & Livestock \& fishery & 0.0441 & 0.0163 \\
3 & Forestry & 0.1933 & 0.0019 \\
4 & Mining & 0.0277 & 0.0032 \\
5 & Processing \& manufacturing & 0.2354 & 0.3392 \\
6 & Power & 0.0006 & 0.0402 \\
7 & Construction & 0.0191 & 0.0137 \\
8 & Transportation & 0.0561 & 0.1370 \\
9 & Communication & 0.0019 & 0.0188 \\
10 & Financial & 0.0004 & 0.0557 \\
11 & Social \& administrative & 0.0000 & 0.0495 \\
12 & Rental \& other services & 0.0003 & 0.1617 \\
13 & Trade & 0.1107 & 0.1641 \\
\hline
\end{tabular}

Source : Model output
Table 6. Multiplicative effect of sectors in Myanmar (2000-2001)

\begin{tabular}{clcc}
\hline No & \multicolumn{1}{c}{ Sector } & $\begin{array}{r}\text { Power of } \\
\text { dispersion }\end{array}$ & $\begin{array}{c}\text { Sensitivity of } \\
\text { dispersion }\end{array}$ \\
\hline 1 & Agriculture & 0.691 & 2.214 \\
2 & Livestock \& fishery & 1.022 & 0.629 \\
3 & Forestry & 0.980 & 0.602 \\
4 & Mining & 1.077 & 0.650 \\
5 & Processing \&manufacturing & 1.240 & 2.584 \\
6 & Power & 0.946 & 0.589 \\
7 & Construction & 1.358 & 1.022 \\
8 & Transportation & 1.094 & 1.260 \\
9 & Communication & 0.766 & 0.608 \\
10 & Financial & 1.039 & 0.579 \\
11 & Social \& administrative services & 1.156 & 0.577 \\
12 & Rental \& other services & 0.743 & 0.582 \\
13 & Trade & 0.884 & 1.099 \\
\hline
\end{tabular}

Source : Model output

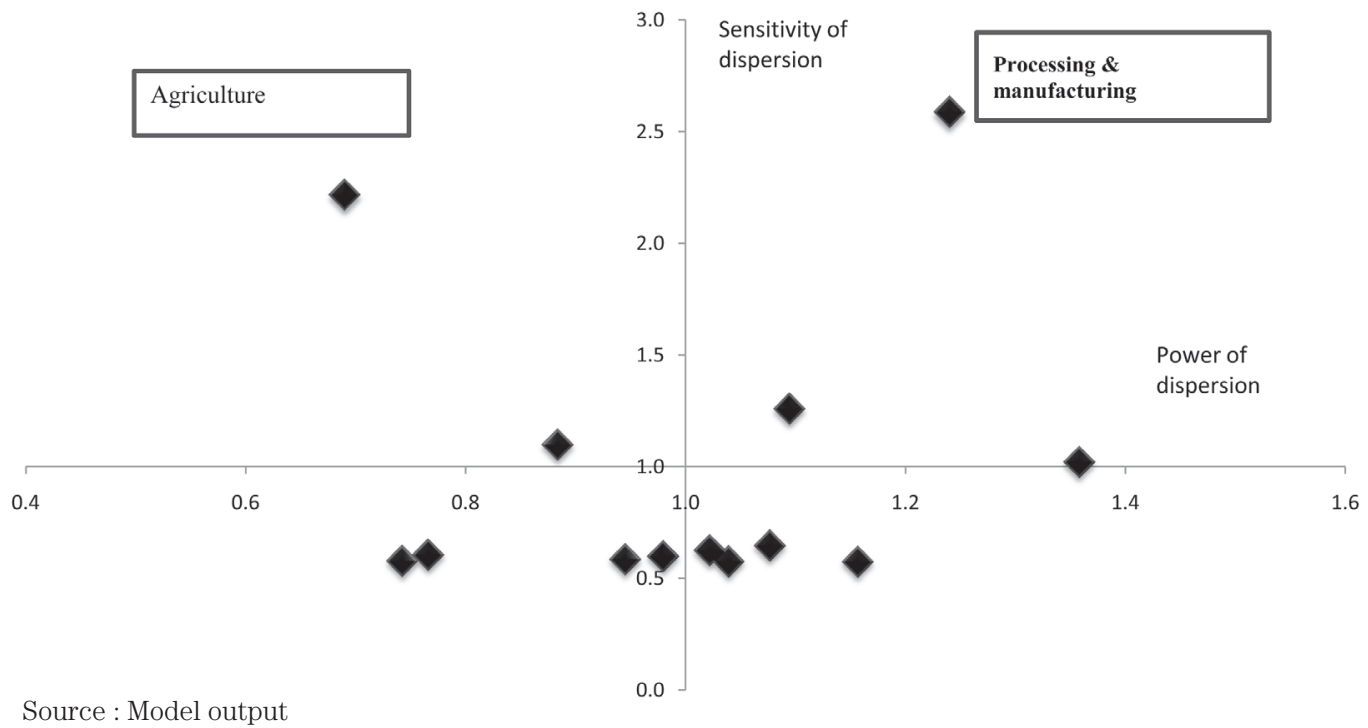

Figure 3. Multiplicative effect of sectors in Myanmar (2000-2001). 
Where, $\beta_{i}=\sum_{j=1}^{n} b_{i j}$ and it is the horizontal sum of row sector of inverse matrix, $\bar{\beta}=\sum_{i} \beta_{i} / n$.

The results of power of dispersion of sector can tell the effect of the growth of certain column sector upon all industries and that of sensitivity of dispersion determine the effect of the growth of all industries upon certain row sector. The above figures [figure (3) and figure (4) ] show the result of multiplicative effect of each sector in Myanmar and Japan in (2000-2001). These results present that the processing \& manufacturing sector is high in both power and sensitivity of dispersion in Myanmar economy and Japan economy. It can be concluded that the growth of that sector can stimulate not only on the growth of economy but also on that of other sectors. In

Table 7. Multiplicative effect of sectors in Japan (2000)

\begin{tabular}{rlcc}
\hline No & \multicolumn{1}{c}{ Sector } & $\begin{array}{r}\text { Power of } \\
\text { dispersion }\end{array}$ & $\begin{array}{c}\text { Sensitivity of } \\
\text { dispersion }\end{array}$ \\
\hline 1 & Agriculture & 0.944 & 0.711 \\
2 & Livestock \& fishery & 1.219 & 0.664 \\
3 & Forestry & 0.879 & 0.677 \\
4 & Mining & 1.119 & 0.597 \\
5 & Processing \&manufacturing & 1.229 & 2.448 \\
6 & Power & 0.936 & 0.818 \\
7 & Construction & 1.138 & 0.710 \\
8 & Transportation & 1.070 & 1.179 \\
9 & Communication & 0.949 & 0.803 \\
10 & Financial & 0.873 & 1.025 \\
11 & Social \& administrative services & 0.885 & 0.722 \\
12 & Rental \& other services & 0.905 & 1.662 \\
13 & Trade & 0.855 & 1.985 \\
\hline
\end{tabular}

Source : Model output
Myanmar economy, agricultural sector is high in sensitivity of dispersion only. In the case of Japan, agricultural sector is low in power and sensitivity of dispersion than other sector. This is because the activities of food processing industry is not play the main role in Japan economy and that of food processing industry play the important role in Myanmar economy.

One sector exogenous model: the effect of $10 \%$ changes in production of each sector upon GDP (Yoshida 1990)

One sector exogenous model assumes one of the sectors in the economy as an exogenous sector while other sectors are endogenous sectors and analyze the effect of changes in production of each exogenous sector upon GDP of the country. In this study, we assume all the thirteen economic sectors be exogenous sector alternatively and change in production be $10 \%$.

This model consists of input-output model with demand and supply identity. That is, $A X+F=X \longrightarrow(I$ -A) $X=F$.

Where, $\mathrm{A}=$ Technical coefficient, $\mathrm{X}=$ Gross output of each sector, $\mathrm{F}$ = Final demand of each sector, I = Identity matrix

Assuming that $(\mathrm{I}-\mathrm{A})=\mathrm{D}$, ' $\mathrm{G}$ ' be exogenous sector and ' $\mathrm{N}$ ' be endogenous sectors and can be defined as follow; $\Delta X_{N}$ $=\left(-D_{N N}{ }^{(-1)} D_{N G}\right) \Delta X_{G}$

Where $\Delta \mathrm{X}_{\mathrm{N}}$ is the change in production of endogenous sectors and $\Delta \mathrm{X}_{\mathrm{G}}$ is the change in production of exogenous sector.

In here, the part of effect of change in GDP with respect to change in production of one exogenous sector can be defined as ;

$$
\Delta G D P=\hat{V}\left[\begin{array}{l}
\Delta X_{G} \\
\Delta X_{N}
\end{array}\right]
$$

Where, $\hat{V}=\left[\begin{array}{ccc}{ }^{v_{1}} & & 0 \\ & \ddots & \\ 0 & & v_{n}\end{array}\right]$ and it is the diagonal matrix of

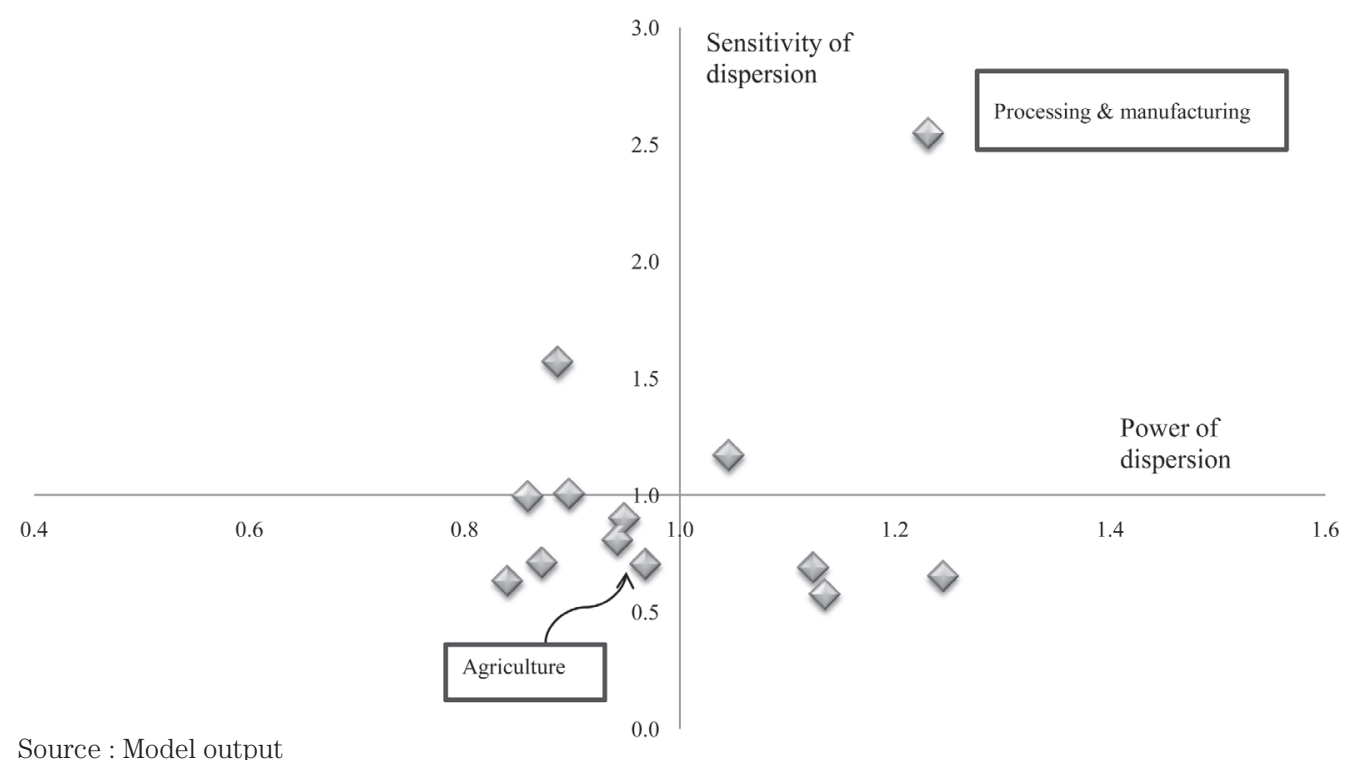

Figure 4. Multiplicative effect of sectors in Japan (2000). 


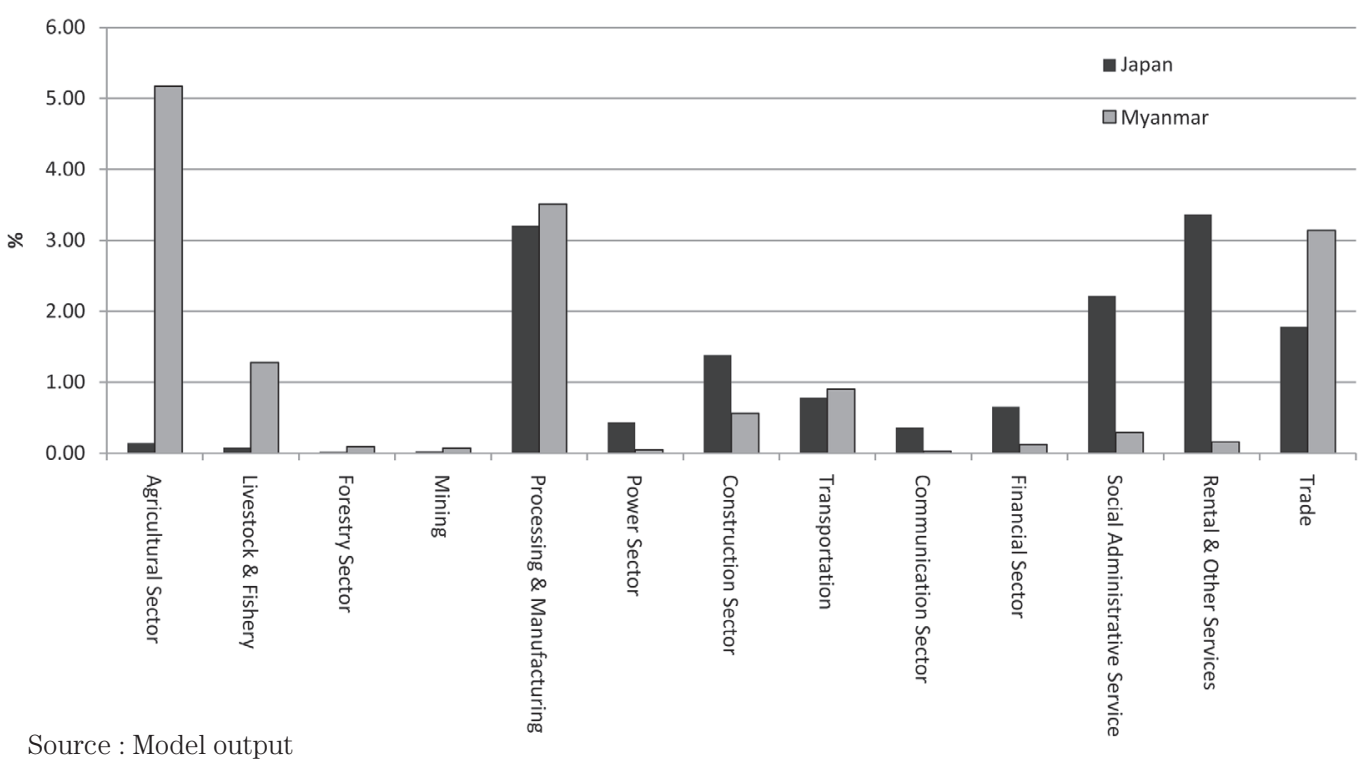

Figure 5. Comparison between the effect of 10\% changes in production of each sector upon GDP of Myanmar and Japan.

Table 8. Comparison between the effect of $10 \%$ changes in production of each sector upon GDP of Myanmar and Japan (The results of one sector exogenous model)

\begin{tabular}{rlcc}
\hline No & \multicolumn{1}{c}{ Sector } & $\begin{array}{c}\text { Myanmar } \\
(\%)\end{array}$ & $\begin{array}{c}\text { Japan } \\
(\%)\end{array}$ \\
\hline 1 & Agricultural sector & 5.17 & 0.14 \\
2 & Livestock \& Fishery sector & 1.28 & 0.07 \\
3 & Forestry sector & 0.09 & 0.02 \\
4 & Mining sector & 0.07 & 0.03 \\
5 & Processing \& Manufacturing sector & 3.51 & 3.20 \\
6 & Power sector & 0.05 & 0.43 \\
7 & Construction sector & 0.56 & 1.38 \\
8 & Transportation sector & 0.90 & 0.73 \\
9 & Communication sector & 0.03 & 0.36 \\
10 & Financial sector & 0.12 & 0.65 \\
11 & Social \& Administrative services sector & 0.29 & 2.21 \\
12 & Rental \& other services sector & 0.16 & 3.36 \\
13 & Trade sector & 3.14 & 1.78 \\
\hline
\end{tabular}

Source : Model output

value added ratio.

Table (8) and figure (5) designate the results of one sector exogenous model and explained that the effect of change in production of agricultural sector is $5.2 \%$ and it is the largest among thirteen economic sectors in Myanmar economy. From this facts it can be said that the production of agricultural sector is the most important for increasing GDP of Myanmar's economy. After that, the production of trade sector and that of processing \& manufacturing sector is the second and third important for increasing country's GDP. In the case of developed country, Japan, the production of rental \& other services sector is the most important and that of processing \& manufacturing sector and social \& administrative services sector are the second and the third respectively for enlargement of country's GDP.

\section{CONCLUSION AND RECOMMENDATION}

This study comprised two parts, one is the estimation of new input-output table of Myanmar (2000-2001) and the second is the analysis of characteristics of industrial structure of Myanmar's economy in that period. Leontief's input-output model and RAS method were used to construct the new and balance input-output table. Induced domestic product, one sector exogenous model and multiplicative effect of sector were applied to analyze the feature of industrial sector of the economy. In addition, the comparison between the input-output table of Myanmar and Japan was made for showing the differences in sectoral activities between developed and developing country.

According to the result of construction of new inputoutput table of Myanmar, it can be concluded that almost all economic sectors require inputs from at least six different sectors. The processing \& manufacturing sector needs inputs from eleven economic sectors. This indicates that this sector has the highest dependency to the other entire sector. The largest input use of processing \& manufacturing sector is from agricultural sector. This is because this sector includes a large number of small scale agricultural based industries.

Although some results of analysis showed that the production of agricultural sector is greatly influenced for increasing GDP and export of our country, induced domestic product by total final demand item of agricultural sector is relatively small compared with non agricultural country, Japan. Base on these results, we can suggest to the policy makers to emphasize more on the domestic production of agricultural sector. The result of multiplicative effect of sector showed that the growth of processing \& manufacturing sector can motivate that of other industries and vice-versa. The growth of all industries can stimulate that of agricultural sector in Myanmar econ- 
omy. In Japan economy, the development of other sector cannot motivate that of agricultural sector. It can be interpreted that it is essential to encourage the improvement of other sectors especially processing \& manufacturing sector for upgrading agricultural sector of Myanmar economy.

Eventually, most of the results of this study have revealed that agricultural sector and processing \& manufacturing sector are the two most important sectors for the development of our economy. It is recommended that our government should pay attention on those two sectors by giving the policy priority and invest priority on those two sectors. It is essential to increase the production of these two main sectors for the extension of primary inputs market and enhancing GDP and export of Myanmar.

\section{ACKNOWLEDGEMENT}

The author would like to offer the heartiest thanks to U Aung Hlaing, Daw Tin Tin Yu and Daw Hnin Yu Lwin for providing their kind help in the collection of the data for this study.

\section{REFERENCES}

Bon, R., and R., Pietroforte, 1990 Historical comparison of construction sectors in the United State, Japan, Italy and Finland using input-output tables, Construction Management and Economics, 8: pp. 233-247

Benjimin, L. Buetre and Z. Ahmaid, Esfahani, 2000 Updating an input-output table for using policy analysis, The Australian journal of agricultural and resource economics, 44: 4, pp. 573-603

Myint, C. C., 1996 Input-output analysis and its application to
Myanmar economy (1989-90) Un-published M. Econ thesis, Yangon Institute of Economics, Myanmar

Chiang, Alpha C., K., Wainwright, 2005 Fundamental methods of mathematical economics, fourth edition, Mc Grew-Hill Companies, Inc..., New York

Donald, A. Glichrist, V. St Louris, Larry, 1999 Completing inputoutput tables using partial information, with an application to Canadian Data, Economics system research, Vol. 11, No. 2

Leontief, W. W, 1951 The structure of American Economy (19191939), An empirical application of equilibrium analysis, New York, Oxford University

Leontief, W. W, 1986 Input-output economics, second edition, New York, Oxford University

Management of coordination agency, March, 1995 Input-output table for Japan 1990, summary in English, Tokyo, Japan

Central statistical organization, 2003 Statistical year book, Ministry of National Planning and Economic Development, Yangon, Myanmar

Thwin, N. K. S., T., Yoshida, K., Maeda, September, 2009 Situation of Myanmar economy using a new estimated input-output table (2000-2001), Agriculture and food resource association conference, Saga, Japan

Nathani, C., M., Wickart, R., Oleshak, R., Nieuwkoop, July, 2006 Estimation of Swiss input-output table for 2001 Center for energy policy and economics Swiss federal institutes of technology, CEPE report, No. 6

Richardson, H. W, 1972 Input-output and regional economics, Weidenfelf and Nicolson, London

Stone, R., 1947 Measurement of national income and the consumption of social accounts, United Nation, Geneva

Stone, R., 1961 Input-output and national accounts, Organization of European economic cooperation

Yoshida T., April, 1990 An input-output analysis on the inter-relationship between the agricultural sector and other sectors (Japanese), Quarterly journal agricultural economy, volume 44, No. 2, National research institute of agricultural economics , Ministry of Agriculture, Forest and Fishery, Japan

Yu, T. T., 1976 Input-output analysis and its application to Myanmar economy (1985-86), Un-publish M. Econ Thesis, Yangon Institute of Economics, Myanmar

Appendix: Input-output table of Japan for the year (2000) (13 sectors aggregated table) (Billion yen)

\begin{tabular}{|c|c|c|c|c|c|c|c|c|c|c|c|c|c|c|c|}
\hline No & Sector & 1 & 2 & 3 & 4 & 5 & 6 & 7 & 8 & 9 & 10 & 11 & 12 & 13 & $\begin{array}{c}\text { Total } \\
\text { Intermediate } \\
\text { Use (14) }\end{array}$ \\
\hline 1 & Agricultural & 484.4 & 368.8 & 1.4 & 0.0 & 3431.9 & 0.0 & 139.6 & 1.6 & 0.0 & 0.0 & 131.6 & 577.5 & 8.6 & $5,145.5$ \\
\hline 2 & Livestock \&Fishery & 52.4 & 339.4 & 2.5 & 0.0 & 3163.6 & 0.0 & 0.0 & 0.4 & 0.0 & 0.0 & 77.1 & 350.4 & 0.0 & $3,985.9$ \\
\hline 3 & Forestry & 2.3 & 1.2 & 190.2 & 0.5 & 355.5 & 0.0 & 11.8 & 0.0 & 0.0 & 0.0 & 2.7 & 25.5 & 0.0 & 589.7 \\
\hline 4 & Mining & 0.0 & 0.0 & 0.2 & 3.3 & 635.6 & 55.3 & 670.7 & 0.0 & 0.0 & 0.0 & 3.1 & 1.0 & 0.0 & $1,369.3$ \\
\hline 5 & Processing \& Manufacturing & 1032.2 & 1196.6 & 80.7 & 89.2 & 109106.4 & 1533.7 & 20428.0 & $5,620.3$ & 451.6 & $1,243.8$ & $12,409.9$ & $16,987.0$ & $3,121.1$ & $173,300.5$ \\
\hline 6 & Power & 49.1 & 34.5 & 8.3 & 43.1 & 6338.3 & 1623.3 & 539.3 & 888.3 & 318.3 & 225.8 & $3,458.9$ & $3,347.5$ & $1,226.2$ & $18,100.9$ \\
\hline 7 & Construction & 51.2 & 26.7 & 3.1 & 9.1 & 1287.1 & 1258.7 & 199.0 & 479.1 & 173.9 & 150.3 & $1,324.4$ & $3,468.4$ & 548.2 & $8,979.2$ \\
\hline 8 & Transportation & 305.7 & 237.8 & 74.0 & 378.9 & 8136.5 & 710.1 & 3985.9 & $3,733.5$ & 483.0 & 713.5 & $2,460.7$ & $3,112.6$ & $4,533.5$ & $28,865.8$ \\
\hline 9 & Communication & 2.0 & 8.6 & 1.3 & 9.0 & 1114.6 & 142.0 & 937.0 & 359.7 & $2,583.3$ & 825.7 & $1,357.2$ & $4,226.9$ & $2,513.2$ & $14,080.4$ \\
\hline 10 & Financial Sector & 319.2 & 166.0 & 17.2 & 65.9 & 4013.7 & 761.1 & 863.4 & $2,920.9$ & 503.0 & $2,667.9$ & $1,031.0$ & $9,152.3$ & $4,926.3$ & $27,407.9$ \\
\hline 11 & $\begin{array}{l}\text { Social \& Administrative } \\
\text { Services }\end{array}$ & 6.0 & 6.7 & 3.3 & 4.9 & 10408.9 & 429.9 & 273.8 & 134.3 & 338.3 & 96.7 & 898.3 & $1,326.0$ & 196.9 & $14,124.1$ \\
\hline 12 & Rental \& Other Services & 162.7 & 97.2 & 17.9 & 87.8 & 14643.1 & 2624.3 & 6450.5 & $7,384.2$ & $3,615.8$ & $5,573.9$ & $8,504.2$ & $17,499.1$ & $9,354.5$ & $76,015.4$ \\
\hline 13 & Trade & 353.3 & 282.8 & 29.7 & 23.3 & 16255.9 & 391.9 & 4942.9 & $1,644.9$ & 95.7 & 190.9 & $3,475.9$ & $5,468.4$ & 735.7 & $33,891.4$ \\
\hline 14 & Total Purchase & 2820.5 & 2766.4 & 429.9 & 714.9 & 178891.2 & 9530.3 & 39442.0 & $23,167.4$ & $8,563.0$ & $11,688.4$ & $35,135.0$ & $65,542.5$ & $27,164.3$ & $405,855.9$ \\
\hline 15 & Imports & 114.4 & 160.3 & 3.4 & 7.1 & 22639.1 & 2185.3 & 1410.3 & $1,847.1$ & 285.3 & 434.8 & $1,074.9$ & $2,239.9$ & $1,146.7$ & $33,548.7$ \\
\hline 16 & Labor Cost & 570.1 & 409.5 & 295.8 & 248.8 & 53108.7 & 4715.4 & 26795.5 & $14,807.6$ & $5,859.8$ & $12,493.1$ & $63,994.0$ & $45,034.2$ & $47,256.8$ & $275,589.1$ \\
\hline 17 & Depreciation & 1054.0 & 394.3 & 48.9 & 123.8 & 16676.9 & 5030.6 & 4059.1 & $3,046.2$ & $3,809.6$ & $3,432.4$ & $16,349.1$ & $34,523.4$ & $4,801.8$ & $93,350.0$ \\
\hline 18 & Taxes (indirect) & 408.7 & 146.5 & -20.9 & 58.8 & 14377.4 & 1491.5 & 2915.0 & $1,432.3$ & 720.4 & -170.8 & -240.3 & $9,473.0$ & $4,256.2$ & $34,847.8$ \\
\hline 19 & Surplus (profit or Losses) & 3207.7 & 894.8 & 665.4 & 225.2 & 22468.0 & 4051.3 & 2688.7 & $3,606.3$ & $2,901.3$ & $10,271.5$ & $4,445.4$ & $47,947.4$ & $12,321.9$ & $115,694.9$ \\
\hline 20 & Value added & 5240.4 & 1845.1 & 989.3 & 656.6 & 106630.9 & 15288.8 & 36458.2 & $22,892.4$ & $13,291.2$ & $26,026.2$ & $84,548.2$ & $136,978.0$ & $68,636.7$ & $519,481.9$ \\
\hline 21 & Total inputs & 8175.4 & 4771.8 & 1442.6 & 1378.7 & 308161.2 & 27004.4 & 77310.5 & $47,906.9$ & $22,139.5$ & $38,149.5$ & $120,758.1$ & $204,760.4$ & $96,947.6$ & $958,886.5$ \\
\hline
\end{tabular}




\begin{tabular}{|c|c|c|c|c|c|c|}
\hline \multirow{2}{*}{ No } & \multirow{2}{*}{ Sector } & \multicolumn{4}{|c|}{ Final Use (Demand) } & \multirow{2}{*}{ Total Output } \\
\hline & & Consumption & Investment & Export & Total Final Demand & \\
\hline 1 & Agricultural & $2,955.7$ & 61.8 & 12.5 & $3,029.9$ & $8,175.4$ \\
\hline 2 & Livestock \&Fishery & 524.7 & 203.2 & 58.0 & 785.9 & $4,771.8$ \\
\hline 3 & Forestry & 152.5 & 678.7 & 1.6 & 832.8 & $1,422.6$ \\
\hline 4 & Mining & -7.1 & 5.6 & 10.9 & 9.4 & $1,378.7$ \\
\hline 5 & $\begin{array}{l}\text { Processing \& } \\
\text { Manufacturing }\end{array}$ & $55,123.9$ & $33,150.5$ & $46,586.4$ & $134,860.7$ & $308,161.2$ \\
\hline 6 & Power & $8,872.4$ & 0.0 & 31.0 & $8,903.4$ & $27,004.4$ \\
\hline 7 & Construction & 0.0 & $68,331.3$ & 0.0 & $68,331.3$ & $77,310.5$ \\
\hline 8 & Transportation & $14,009.5$ & 770.8 & $4,260.8$ & $19,041.1$ & $47,906.9$ \\
\hline 9 & Communication & $8,006.9$ & 0.0 & 52.2 & $8,059.1$ & $22,139.5$ \\
\hline 10 & Financial & $10,346.0$ & 0.0 & 395.5 & $10,741.6$ & $38,149.5$ \\
\hline 11 & Social \& & & & & & \\
\hline & $\begin{array}{l}\text { Administrative } \\
\text { Services }\end{array}$ & $106,577.0$ & 0.0 & 57.0 & $106,634.0$ & $120,758.1$ \\
\hline 12 & Rental \& Other & & & & & \\
\hline & Services & $116,909.0$ & $10,307.0$ & $1,529.1$ & $128,745.0$ & $204,760.4$ \\
\hline 13 & Trade & $47,786.9$ & $10,777.6$ & $4,491.7$ & $63,056.3$ & $96,947.6$ \\
\hline 14 & Total Purchase & $371,257.4$ & $124,286.5$ & $57,486.7$ & $553,030.6$ & $958,886.5$ \\
\hline 15 & Imports & $14,610.2$ & $6,002.3$ & 0.0 & $20,612.5$ & $54,161.2$ \\
\hline
\end{tabular}

*(yen represent the currency of Japan) 